\title{
The Irony of a Handshake of Friendship with the West: A Reflection on Oyono's HouseBoy and The Oldman and the Medal
}

\author{
Dr Kalu, Kalu Obasi ${ }^{1}$ \\ ${ }^{1}$ Veritas University Abuja, The Catholic University of Nigeria, Nigeria \\ Correspondence: Dr Kalu Obasi Kalu, Veritas University Abuja, The Catholic University of Nigeria, Nigeria \\ Received: December 6, 2017 \\ Accepted: February 6, 2018 \\ Online Published: February 23, 2018 \\ doi:10.5430/elr.v7n1p52 \\ URL: https://doi.org/10.5430/elr.v7n1p52
}

\begin{abstract}
The African proverb that 'a set of white teeth does not indicate a pure heart' aptly illustrates the relationship that exists between the Africa and the West. Colonization which is the image of friendship with the White man turns out to be a curse rather than a blessing. The Africans in their brotherhood temperament happily offers a handshake with the White man with the hope fostering a good relationship only to discover that the kind gesture is tampered with bad omen by his guest. The advancement of the White man was a happy thing to the Africans who assumed it to usher in good relationship between the West and the Africans. But it rather turned out to be a curse. Though belaboured in literary criticism, this paper attempts to look at the irony of the handshake as a symbolic image, exposing the White man's wicked impressions as against the good intentions of the Africans. To do this Oyono's Houseboy and The Old Man and the Medal are used for this study. The paper examines the degree of acceptance by the Africans and the humane acceptance of the White man and his eventual exploitative attitude toward the same people who happily accepted them. The White man's use of violence to oppress, subjugate and assault his hosts. The paper explores the ridiculing nature of colonialism and providing the insight to view the psychology of both the White man and his African host. Allusion is also made of other texts that express the same themes.
\end{abstract}

Keywords: irony, handshake, West

\section{Introduction}

French writers like Ferdinand Oyono, Mongo Beti, Peter Abraham, among others wrote their novel in a satirical and ironic forms. This was because they experienced a psychological trauma more the British West African countries. The system of colonization in Cameroon was assimilation. This policy was of total conversion of the Africans into French men. Unlike the indirect rule of the British West African colonies, the French adopted a direct rule of their colonies. They were convinced of the salvage nature of the areas that had thus come under their control. This was inevitably so given their Western yardstick for the measurement of culture and civilization.

As far as they were concerned the ingredients of civilization were deficient in these countries that were immediately classified as primitive. This conviction enabled them to give an altruistic halo to their colonizing mission, which was an expansionist venture into Africa and which was basically materialistic, political and or could almost be disguised as missionary activity meant to bring light to the benighted Africans. The colonialists claimed that their coming was to evangelize and civilize the people of the termed dark continent of Africa. The propaganda of the missionaries themselves actually reinforced this view, because they glaringly believed that Christian Western civilization was better and so had a duty to spread it to members of their acquired colonies. Walter Rodney in How Europe Underdeveloped Africa, described the civilizing mission of the West as "a one-armed bandit” (244). He believes that colonization the Africans, more than anything else underdeveloped Africa. According to him, "colonialism laid the roots of neo-colonialism in Africa by creating Africa's economic dependency on the international capitalist system..." (244).This civilizing mission was at times carried out in the face strong opposition from the political and administrative arm.

The result of this was that African indigenous culture was devalued. Traditional religion was termed paganism and traditional education through the tribe's artisans was regarded as the perpetration of the most barbarous, unhygienic and indecent act. The African people themselves were brainwashed into believing the their culture was primitive and that they could only hope for advancement by espousing Western religion and pseudo-Western life. The French policy of assimilation virtually turned a cream of African traditional society into something else and the Africans 
were put through a thorough French system of education with the intention of making them black French men who completely at home in French culture. School children in Francophone territories were taught to recite that their ancestors were Gauls just like French children.

Walter Rodney reacting to the attitude and impact of colonialism states that:

the limited social services within Africa during colonial times were distributed in a manner that reflected the pattern of domination and exploitation. First of all, White settlers and expatriates wanted the standards of the bourgeoisie or professional classes of the metropoles. They were all the more determined to have luxuries in Africa, because most of them came from poverty stricken homes in Europe....(224-225)

The British colonial government maintained a segregated services and policies among their respective colonies just in the same way as the French colonial masters. But they immensely benefitted from the African, particularly in the economic areas but refused to provide social amenities to the labourers. According to Rodney:

the viciousness of the colonial system with respect to the provision of social services was most dramatically brought out in the case economic activities which made huge profits, and notably in the mining industry....(225-226)

Ferdinand Oyono in his novels gives a reflection of the Cameroon society and the Cameroonians who wrongly believed in the system of the French and became alienated and exploited. He also states in reality what the French imperialists were, as well as what they did to their African subjects within the period of colonization. Oyono attempts to establish the purpose or supposedly the intent of the colonialists in the Cameroonian region of Africa which then underscores the outcome of that purpose within and after the encounter. He criticized the activities of the imperialists which he believes is contrary to what they practiced.

\section{The Irony of Handshake in Houseboy}

A hand shake is the offer of acceptance. This offer results in a great deal and dimensions of exploitation. Oyono in this novel reveals these and communicates them to his fellow Africans in general and to the Cameroonians in particular. Houseboy appears as the most possible indictment and the most passionate denunciation of the French colonial rule in African creative writing. Through the naivety of the hero Toundi, Oyono gains a good view of the various levels of exploitation in the African society of the Cameroons and comes into realization that the African man though detached from his traditional system by Western cultural civilization will ever remain what he is irrespective of his supposed acculturation by the Western world.

The White man, Father Gilbert offers a hand shake to Toundi, the hero of the novel, through the booby-trap of sugar and is drawn away from his traditional home. This incident took place on the eve of his initiation to manhood, to become the house boy of Father Gilbert. The naivety of Monsieur Toundi makes him declare, "My ancestors were cannibals. Since the White men came we have learnt that other men must not be looked upon as animals".(9). This is a true evaluation of the Whites about the Blacks. But this becomes a true evaluation of the Blacks by the White colonialists. It purely an irony because Toundi is eventually treated as an animal by the same White men he claims have made them not regard any fellow man as animal. The same White man who preaches universal brotherhood sees and treats him as such. Toundi was kicked and pulled in the ears like a dog. He himself confirmed this when Oyono makes him to say that; " A dog of the Father was the king of dogs"(20). The manner by which Toundi was attracted to the White world is coterminous to a hand shake of exploitation and this gives a satirical note not only to Toundi and his folks but to the White man's religious creed.

Toundi is attracted to satisfy his greed of going close to the White man with hair like the "beard of maize cob, who dressed in women's clothes and gives little Blackboys lumps of sugar"(11). Here, while Toundi and his comrades own their portion of satire, the White man's moral depravity and the spiritual bankruptcy of the Roman Catholic church whose priest attracts boys to Christianity by throwing lumps of sugar to them is exposed bare. This actually earned Toundi his alienation and his eventual death. Confirming the comment of his mother about the result of greediness he says that; "My mother often used to say laughing, Toundi what will your greediness bring to you" (12). This means that a man who gives himself to White man as a friend is bound to die. The White man looks good and humane but inside him is buried the evil tendencies of depravity.

A hand shake of friendship with the White man means an uncalculated alienation, separation from traditional African reality. This implies a mischievous engagement and leads to death. The comment of his mother was rhetorical but was confirmed when he realized his folly on his dying bed. Toundi was to be initiated into his 
traditional manhood before he becomes drawn away into the Western world through Father Gilbert and the Commandant. He saw the traditional education as savage as against the Western education which he was going to learn through the Father. This makes Toundi to turn his back on the traditional life and on all of his ancestors when he should have met the famous serpent that watches over all the men of his race.

Father Gilbert accepted Toundi as his houseboy without having a reflection of asking about his parents. Courtesy demands that Father should have shown and expressed happiness upon the sight of his house boy's father and give a warm welcome. But the reverse was the case. Toundi's father was rather insulted before his son by Father Gilbert, and Toundi is complacent about it. Oyono records this event as being contrary to the professed Christian belief and friendly relationship which the White imperialists came with in the first place. Despite Toundi's likeness for Father Gilbert, he was not shown passionate love but was rather treated like a pet animal by his master who also showed him off to his friends as his masterpiece. The same inhuman attitude was shown to a Black girl Sophie who was offered a handshake of friendship by an agricultural engineer. She was sexually exploited by the and she declares that; " The White... have no regards for the Blacks and should be exploited at the least opportunity available” (21). She laments that the Blacks were treated as second best and states her tiredness thus:

I'm tired and sick of hearing Sophie, don't

Come today. I've got a European coming to see

Me at the house, Sophie you can come,

the European has gone (21).

She continues her explanation of the attitude of her White friend that, "Sophie when you see me with a White lady, don't look at me, don't greet me" (22). These situations are elements of the irony of friendship, a handshake with the White man. Relationships with the White man have brought misery to the Blacks and have estranged them in their own fatherland. As Father Gilbert dies, Toundi becomes the house boy of the commandant through whom Toundi's eyes are opened to certain realities of the White man's hidden personality. He is initiated into his new master's household by an act of wanton brutality on the part of the burly commandant. Toundi ironically describes him as "the kind of man we call mahogany trunk"(32) because the trunk of a mahogany is so strong that it never bends in a storm.

Toundi who thought he was going to live like a White man French man was so humanly disillusioned and used that the skin of his knees became hardened due to regular use. While he lived with Father Gilbert, he served mass and did other household chores without any pay, but he rather received brutal treatment like a pet animal when he misbehaved. Living with Father Vandermayer, he notices that Father Vandermayer "shouted obscenities when he was ill, hence contradicting his position as a priest" (16). This further exposes the pretentious nature of the White man at the death of Father Gilbert and Toundi is handed over to new master.

The irony of this relationship is that colonial elites attempt to overthrow the masculinity in Toundi because he puts on the apron and performs menial domestic tasks for the White man. This means that no matter how old he becomes as a house boy, he will remain a boy and treated according to his designation of a house boy. In view of this Stoler has noted that " the de-masculinization of the colonized men and the hyper-masculinity of European males represent fundamental assertions of white supremacy" (56). By subduing the sexuality of the uncolonized, the supremacy and imperialistic pose of the Whites is glorified. Toundi in his relationship with the Commandant becomes the source of dispute between the Commandant and his wife. He becomes exposed to many secrets about them. For this reason he is frequently assaulted physically. The Commandant in flagrant contempt frequently stepped on the finger of Toundi so as to deliberately cause him the sensation of pain. He recalls that:

The Commandant trod on my left hand. He was talking to Madame at the time and he went on talking as if he hadn't noticed. He managed to bring his foot down while I was off my guard, giving his boots a final polish before he went out. He has no Memory and no imagination. He forgets he has already tried this on me and it did not make me cry out. As the first time, he just walked on without looking round but this time he went jauntily like a man who feels pleased with himself (102)

When it was noticed by the Commandant and his mistress about Toundi knowledge of their secrets they ironously named him Monsieur Toundi. This means that he acquired much knowledge like the White man and their equal. In such situations it indicates a bad signal when a White man refers to an individual purportedly inferior to them with respect. This is used as an address to Toundi which a sign of impending doom. 
Toundi in his Cameroon world is used to represent a whole nation and set for abuse by the colonial master. Toundi is nonetheless treated and conceived of by his White masters as a household convenience within the terms dictated by his one limiting function - a servant of the White men. It pleases the White man to have the Africans as their servants, taking the best part of the Africans. But with time the African develops consciousness and realizes his identity. This situation agrees with Karl Marx when he states that:

Man's consciousness changes with every change in the conditions of his mental existence, and at a certain stage in their (his) development, the material forces of production in the society comes in conflict with the existing relation of production, and then occurs a period of social revolution. With the change of the economic foundation, the entire immense super structure is more or less rapidly transformed (67-68)

Throughout the novel, Oyono provides a careful explanation of the Whites' inability to understand the Blacks except through diminutive rationalization. Toundi is at first treated as an obscurely talented work donkey, and eventually like some kind of harmful cobra that can strike at any time or spit venom. Toundi is as a result maltreated, the outcome which is depends upon a habit of the mind that is incapable of serving the Black as a whole person let alone as a whole person with rights that are independent of his master's parochial demands. His first encounter with the Commandant gives Toundi a picture of what he was going to be. He says of his master and the encounter that; "After he had looked at me for a long while, he asked me point-blank if I were a thief” (35). The Commandant's sense of priority is astounding. Toundi is scrutinized for clear characteristic as if he were a young scorpion scrutinized for stinging power. Being looked at as a pet animal, Toundi is seen as an object of ridicule and fun by the Europeans.

This represents his savage race as all Blacks are seen to be the same. The White man does not see any difference among the Blacks. They all appear the the same in looks and character. This fact is acknowledged by Toundi as he says; "How can he recognize me? All Africans look the same to them"(32). Toundi was not alone in this treatment. Oyono has pointed out ab initio that any treatment given to Toundi was the same treatment extended to any other Black man. Even though the agricultural engineer sexually exploits Sophie, it does not appear as anything among the Whites who see the Africans as savages that can be used and dumped.

In the same stretch of imagination the dancers at Dangan who came to entertain the Commandant and his entourage were given a shabby treatment. They were allowed to play and dance to entertain the Commandant and his entourage. They did this to the desires of the White up until when they were to have their siesta. The music which they had hitherto enjoyed became a source of noise to them. They had to order for it to be stopped forthwith. The Europeans are friendly only when they have something to benefit from you.

If others could not be recognized because of their lack of contribution to economic development of the European nations, what about chief Akoma and Mengueme who speak and understand the French language well? Akoma was called the chief of rings and wives because he had them in chains. He lost his brother and two sons in the German-French war just like many other Africans who have died the same cause. Apart from the inhuman treatment of Toundi and other Africans, Oyono makes us to see through the naïve eyes of Toundi the absurdities of the religious faith as introduced and practiced among the Dangan community of the African tribe. He describes how he sees the ceremony of Holy Communion as:

All the faithful come up to the altar with their eyes shut, and their mouths open and their tongue stuck out as if they were pulling a face. The Europeans receive communion separately (17).

This passage highlights the discrimination that is practiced in this church. The Africans sit on trunks in the nave while the Europeans are comfortably seated in the transept on cane armchairs covered with velvet cushions. But in spite of the discrimination of the church and the degradation of the Africans, the statue of St. Peter, who has been so blackened by the weather, that it could pass for an African, is conspicuously mounted for all to see. The church is even more savagely denounced in this novel. The church is pictured as a hypocritical agent that aids and abets the imperialist oppressors. The church helps to promote Toundi's corruption by first seducing him and drawing him away from his traditional environment and then handing him over at the mercies of the political administration. Father Gilbert's condenscension and evangelizing activities cause friction in the neighbourhood. This violent is more pronounced in Father Vader Mayer who is more vicious. He beats Christians who commit adultery and make them to undress in his office and asks them “when you were kissing, weren't you ashamed...?” (87). Where Black men are concerned, Father Vander-Mayer is prepared to abuse the sacred ritual of confession because of his predisposition to degrade the African. But nothing of such takes place among the Whites who regard themselves as 
perfect before God. They smoke heavily and stop African faithful from smoking. Adultery is no sin among the as it is noticed about M. Moreau's relationship with Toundi's mistress. Apart from that Kalisia, the new all knowing housemaid to Madam lets us know through the naïve eyes of Toundi that Black houseboys down the coast sleep with their master's wives as much as the liked.

\section{The Irony of Handshake in The Old Man and the Medal}

Oyono's The Old Man and the Medal (1981) is a novel which is used to establish a handshake with the colonial imperialists. The novel expresses his social vision through his themes and character portrayal. The book exposes the plight of his Cameroon encounter with the Europeans through the assimilation policy. Oyono as a socially responsive writer who responds to the colonial discourse which has made Cameroon to be referred as a post colonial state concerns himself with exposing a nation ridiculed by the encounter between Africa and Europe. This encounter enhanced the circumstances under which the West crossed the African historical path. This resulted in a change in the realities of African life. The offer of acceptance given to the colonial masters among the Cameroonians through the assimilation polcy gives vent to the circumstance of irony. The colonial era have had a strong impact on the African experience which has not only been felt physically but also psychologically.

Oyono exposes this irony using Meka his protagonist and other characters in the novel. Meka and his fellow Africans had expressed joy of being African French men. They grew cocoa for export to France and received nothing in return as a reward. The White man admirably makes the Blacks to construct a road through forced labour to link them to France for the exportation of the agricultural produce exploited from African soil by the Africans for the benefit and comfort of the French imperialists. It is ironical that Meka who sacrificed his economy and child for the White, man and who with all degree of enthusiasm defied all odds to move to Doum to receive an award of honour - a medal form the White man was rather disillusioned by being pushed into detention by the same authorities that honoured him. This implies that the White man has no sense of identity for the Black man with whom he lives in the same environment.

Meka is recognized as a friend of the White man. This is shown in the statement:

Meka was sitting beside the White man who was driving. Every now and then he leant out of the window so that everyone in the village could see him...(15)

He had sacrificed his land as a gift to the White man and had lost his two sons fighting for the freedom and security of the same White man. In his exhilaration he informs his countrymen that:

The Commandant called me to tell me that the great Chief of all the White men who is in Timba is coming to give me a medal on the $14^{\text {th }}$ of July...(15)

This should have been a great honour and mark of recognition to a man who has done so much for the White man. Meka reeled out his mind for this and yearned for the D-day to come. It is remarkable that Meka and his other fellow Africans are seated on a bench waiting for the attention of the White man to value their farm produce. Meka is recognized for his stedfast love and sincerity which is acknowledged by his white friends thus:

The White man talked for a long time. The interpreter translated what he had said like this... Meka you are now somebody among men. Since I came to this country Ihave never seen cocoa as well dried as yours... you have done much to forward the work of France in this country...(19)

Come the $14^{\text {th }}$ day of July, Meka is offered an award depicting honour and friendship with the White man. In the euphoria of the award, Meka becomes drunk. That day was concluded with a heavy storm of rainfall. Meka was picked the police after wallowing out of the gutter in his drunkenness and marched to the station for detention for wandering.

The storm should have been a symbol of warning of his relationship with the White man. His ancestors were not happy with that extension of love and to the White man. Hence he lost the medal in the storm and lost his friendship with the White man. Groping in the dark, a glimmer of light offers him hope which was short lived. This was the light of the police sergeant on patrol who arrests him for wandering for wandering. The irony of this is that the light which the White Chief honours him with on the day of the award, but rather turned out against him. It is revealed that, "Before he recovered from his surprise, an iron fist crashed into his stomach, winding him. Meka felt himself lifted up into the air".(122)Meka at this point is not spared any humour but is brutalized and humiliated. His captor declares; " get up, you pig, where are your papers?... where have you come from? What are you doing fucking around here...eh? (122). Pandermonium began with the arrival of Gullet and his men, and everyone runs at different 
directions. Panic spreads throughout the room, bottles are knocked everywhere and no one remembers Meka. It is at this moment that he loses the medal of honour given to him by the Chief of the White man. Without any reservation the constable continues to force and march Meka to move on his way with the statement "on your way my good friend of the Governor...just look at this old devil,. Go on move” (132).

The African's extension of hands of friendship to the White man is a thread into abuse, subjectivity and oppression. Joseph Okpaku (1984) has observed in his work The Art and Civilization of Black African People, that the helplessness of the Africans is in a depicadence nature. He sees the Africans as a people that are denied the basic necessities of man as human beings. He sees the Africans utter cynicism and feels that they are nondescripts, people without an address, hope and identity. It is worthy of note that during the period of colonialism in Africa, the Whites intimidated the Blacks. They also cheated the Africans so much by exploiting them in all manners of human circumstance. By making them eat from the crups of their own labour, theyare denied the benefits and legacy of their labour and toils in their own homeland.

Meka, the protagonist of The Old Man and the Medal ironically loses his relationship with the White man he had given his heart. The constable who picks him up on the day of his decoration and award shouts at him. The constable says" cover up your dirty old arse and show me your papers" (122). It is ironical that the constable who beams his torchlight on Meka, the man whom all the White men, their agents and the entire community of Doum have recognized and honoured with a medal in the broad day light does not recognize him as the same man so soon after. He marches the old man on to see the dreaded Gullet. When Meka sums up courage to address him, he says:

Officer, o my son, I am not a prowler, my son, A Meka has never been a thief! I went to be given the medal of friendship officer! Only the medal of friendship... I am a man among the men of Doum, old child of the rising sun who does not know me! O officer I went to be given the medal of friendship officer! Only the medal of friendship...(125)

It is disgusting that this plea fell on deaf ears as Meka is kept being maltreated and led to Gullet. He is called bad names like tortoise. He is beaten by many police men at once and the Gullet takes out his riding crop andlays it on Meka up to ten times on Meka's shoulders ,he spits on face and finally asks “who is this lunatic?”(133). When Meka realizes who he is, he explains " they can do what they like to me.... He asks me who I am. Tell him I am a very great fool, who yesterday still believed in the White man's friendship...” (135). When Meka realizes himself and his vouched friendship with the Whiteman, he feels a shadow of sadness pass over him. He realizes that the White man only has used him, his strength and his land to his own advantage. This realization spreads over as the natives complain of the wrongs and evils done by the White men to the Africans. Meka remembers Zourian where everyone envies him because of his brother-in-law and remembers that things have become destroyed by the Whites. Engamba, Kelara, Meka's wife, all come to realize the exploitative attitude and the irony of a friendship with the White man.

The irony here is akin to Richard Wright's characters in Black Boy (1942) and Native Son (1941) where Negroes in America in the early 1920s have no rights in America of anything. They cannot live in decent quarters or hold decent job positions and placement. Ralph Ellison's Invisible Man(1952) depicts the same situation. It is at last that the Invisible Man realizes himself and discovers his identity. Rodney describes colonialism as one armed bandit. He claims that colonialism more than anything else underdeveloped Africa. The levels of exploitation have been underscored by many writers and scholars. In the area of labour, Karl Marx states that " exploitation will result in the emergence of class struggles in which the working class will inevitably overthrow their exploiters in a revolutionary combat. (5) He again states that:

Man's consciousness changes with every change in the conditions of his mental existence, and at a certain stage in their development, the mental forces of production in society comes in conflict with the existing relations of production and the occurs a period of social revolution. With the change of the economic foundation the entire immense super structure is more or less rapidly transformed (1956:67-68).

It is remarkable to note that the White man comes with religion and under the guise of civilizing mission on the Africans to then exploit and debase them. This situation is emphasized by Ngugi as he states:

Religion is not the same as God. When the British imperialists came here in 1895, all the missionaries of all the churches held the bible in the left hand, and the gun in the right hand. The White man wanted us to be drunk with religion while he in the meantime, was mapping and grapping our land and starting factories and business on our sweat(1982:56-57). 
Amical Cabral holds the same view as he states that " colonialism by denying to the dominated people their own historical process, necessarily denies them of their cultural process" (142). This is achieved by ensuring that the people are culturally oppressed by the use of direct or indirect measures.

\section{Conclusion.}

The White man has always extended a hand of friendship to the Blacks. Their slogan of civilizing mission has become a proverb in African settings. This measure has been used by the West even now in the form of neo-colonialism to rob Africans of their ancestry, tradition and culture. Any relationship with them brings wisdom in the reversed order to the recipients. There is no doubt that the West brought their civilization to replace those of the countries they colonized, most Africans exploited this situations to find better conditions of existence. They exploited their ill-fated civilizations to their own advantage. It is therefore remarkable that THE West cannot long to be your friend if he nothing to gain from you. Their hands of friendship must always be watched with consciousness and cautious mind. The White man's relationship with the African has basically been exploitative and full of irony.

\section{References}

Cabral, Amical. (1980).Unity and Struggle. London: Heinemann.

Ellison, Ralph. (1952). Invisible man. London: Longman.

Marx, Karl \& Engels Fredrick. (1988). Manifesto of the Communist Party. Moscow: Foreign Language Press.

Okpaku, Joseph. (1968). The Art and Civilization of Black African People 3. New York: Third Press.

Oyono, Ferdinand. (1968). Houseboy. London: Heinemann.

Rodney, Walter. (1968). How Europe Underdeveloped Africa. Tanzania: Tanzanian Publishing Press.

Wa Thiong’o, Ngugi. (1988). Writing Against Colonilism (ed) Petersen, K.H. Criticism and Ideology; Second African Writers Conference. Stockholm.

Wright, Richard. (1970). Black Boy. New York: Longman.

· . . (1972). Native Son. New York: Longman.

. . (1967). The Old Man and the Medal. London:Heinemann,1967.

· . (1987). Decolonizing the Mind: the Politics of Language in African Literature. Harere: Heinemann.

. . . (1982). Devil on the Cross. Harere: Heinemann. 